\title{
Predicting Consumers' Behavioral Intentions with Perceptions of Brand Personality: A Study in Cell Phone Markets
}

\author{
Murat Akın \\ School of Economics and Business Administration, Niğde University, Niğde, Turkey
}

Tel: 90-388-225-2050Ｅ-mail: murat.akin1@gmail.com

Received: December 8, $2010 \quad$ Accepted: January 13, $2011 \quad$ doi:10.5539/ijbm.v6n6p193

\begin{abstract}
Although there are many factors affecting the attitude and intention of the consumer, it could be said that personality is the most important among them. Differentiating the products, which are getting more similar today, becomes more difficult for the firms. In differentiating the products emotional factors come to the forefront. If the characteristics of the product are subjective and difficult to evaluate, consumers start to trust brand personality. The importance of brand personality is increasing nowadays. The reason is that brand personality increases the trust and loyalty of the consumers for the brand by affecting costumers' preferences and uses. Pragmatic and personality factors have determinative effects on the formation of consumers' attitude toward product and brand. In this study, it is examined whether the perceptions of costumers about brand personality of cell phones affect their behavioral intention, or not. The answers of the 390 respondents, to whom questionnaires are applied with judgment sample method, are identified by brand personality scale adapted for Turkey by Aksoy and Özsomer because of cultural differences. A four dimensional structure is constructed in the study as Aksoy and Özsomer indicated in their work. The study shows that the dimensions of competency and excitement have higher impact on behavioral intention than the dimensions of traditionalist and androgen. The characterization of a technological product such as cell phone as competent proves that the global firms operate in this sector are in the right direction.
\end{abstract}

Keywords: Personality, Brand personality, Cell phone

\section{Introduction}

Firms have been developing new products for differentiation in markets due to fierce competition for the last 20 years (Thomas and Sekar, 2008). Rivals can easily copy a new product that is developed for differentiation thanks to the technological progress at short notice. This makes firms seek different ways along with strategies to develop new products and their features. Effective brand management is an important competitive advantage for firms under increasing competition (Eisend and Langer, 2007).

Differentiation a product in its category has been an important marketing strategy today when brands are similar to each other in terms of quality, price, distribution (Çifçi and Cop, 2007). Emotional factors should be emphasized more to differentiate a product. Abstract and emotional factors forming a brand are more influential than concrete and rational ones in positioning a brand or product. Therefore firms are turning to abstract and emotional factors today. It is seen that consumers trust brand personality more when product features are difficult to be evaluated or subjective. Brand personality also plays the most important role in final purchase decision and makes the brand be more advantageous than those of rivals (Büyükyavuz, 2008).

In mature and dense markets, much effort is needed for brand positioning. The perceived quality of products does not vary much today and it has been difficult to develop new product features for differentiation. Additionally, with the help of developing technologies, newly-developed product features can be easily imitated. Therefore, using differentiation strategies is a must in positioning a brand (Aaker, 1997).

Positioning a brand as generic name may cause market share loss since it is perceived as an ordinary thing. When price differentiation is taken into consideration, it also may weaken the firm's control mechanisms although it seems easy. However, using personality traits in positioning brand helps firms increase consumers' preference, loyalty and trust (Aksoy and Özsomer, 2007). Accordingly, it has an important effect on consumer purchase intention. 
The most difficult and complex aspect of building a brand is personalizing it. Brand personality is seen as a strategic tool for both building and managing brand by both academicians and practitioners. Building a strong brand can be possible by designing and conducting proper and effective brand personality. In unstable and dynamic markets, firms should promote their right brands with suitable brand personality which can be accepted by consumers (Keller, 2003: 638).

The brand becomes differentiated from similar brands which have same features with the help of unique brand personality created. According to Aaker, brand personality is created when consumers attribute personality traits which help them distinguish brands to a brand (Xue et al., 2007). Firms should decide which brand personality traits their brand personality will have for a product brand or brand name since the meaning of a brand in the life of consumer comes from the positioning of the brand and the image it creates. Also, the image which a brand creates in consumers' minds depends on brand personality (Dursun, 2009).

When building a brand personality, probably the most important factor is whether there is a closeness between the intended brand personality and consumers' personality in target market as when brand personality is close to that of consumer or the admired, his purchase intention to buy brand and brand loyalty is bigger (Yilmaz, 2007).

Brand personality is a strategic tool that forms the communication between brand and consumers. Brands can reflect and tell themselves in consumers' minds by means of personalities. At this point, brand personality plays a key role in building loyaler relations or moving up the differentiation ladder in consumers' minds. Brand personality is about general style and attitude when conveying the message, so brand personality is an important factor in building emotional connection. When building a personality in connection with brand, it is necessary to know the conditions and circumstances in which consumers prefer the brand and accordingly, suitable image and emotion forms (archetypes) should be chosen. When brand personality is based on an archetype, it is noticed more easily and it finds better place in the minds of the consumers (http://markakimlik.blogspot.com, 23/03/2010).

Consumers' purchase preference is based on information they collect. Consumer who has to make purchase decision without information feels himself under risk due to uncertainty, so he looks for cues. In this step, brand and its meaning to consumer and associations (archetype) play important role in purchase preference (Kurtuluş, 2008).

It is asserted in the studies on brand personality that personality attributed to brand is in fact a symbolic usage. The personality brand represents is a tool that can be used as an indicator that shows "whether it is worth buying or not" in consumer psychology (Nart, 2008).

Although there are many factors affecting attitude and intentions, personality is the first one that should be taken into consideration by researchers. Ratchford and Vaughn state in their works that conditional and personality factors have important and decisive effects on forming attitudes and intentions of consumers for product or brand (Shavitt, 1989). In literature, there are lots of findings which prove that consumer is affected by behavioral intentions such as how to make consumer buy and pay more, developing his brand preference, make them tell others good things about brand (Dursun and Çerçi, 2004; Hayes, 1999). The study is aimed to examine brand personality perception in connection with consumers' behavioral intentions. Although there are many factors affecting attitudes and intentions of consumer, personality is especially an important one that should be paid attention by marketers.

\section{Personality}

Personality can be defined as all distinctive and unique behaviors of individual. The word "Person" comes from "Persona" (Latin) meaning mask people wore according to their roles in theatre (Soysal, 2008: 6). Personality can be also defined as organized set of physical, intellectual and spiritual and characteristics possessed by a person that make him different from others (Erkal, 2004; www.donusumkonagi.net, 26/02/2010). It can also be stated that personality is a kind of established, consistent and distinctive relation, including reactions, with others (Çetin and Beceren, 2007).

According to another definition, personality is set of fixed features and behavioral patterns that help individual suit his environments (Dursun, 2009). Personality causes people to evaluate everything around them by means of their personal traits. Sometimes, people in shopping centers say "This cloth does not reflect my personality" or "This reflects my character" (Mishra and Detta, 2008).

Schiffman and Kanu state that the definition of personality should be based on the following three items (Çetin 2009; Uztuğ, 2003; Odabaşı and Barış, 2003): 
- Personality makes an individual different from others

- Personality is consistent and permanent

- Personality may change

\section{Personality Measurement}

Psychology, throughout history, has attempted to establish the systematic and generalisable framework which explains the differences between individuals. A number of personality theories have been developed in order to determine the similarities and differences between individuals and to seek how these similarities and differences organize as a form or model. In ancient Greece, it used to be accepted that the physical and spiritual health of an individual depended upon the balance between four body liquids, that each personal characteristic or trait stemmed from one of them. According to that, blood would cause an excited personality, black gall would cause melancholy, yellow gall would cause an angry personality and sputum would cause a reckless personality. Also, the amount of these liquids in the body would determine the mood of the individual (http://www.bilgininadresi.net/Madde/33235, 20/03/2010).

Systematic approaches started in 1884 with Galton, who took the words related with personality in English language into consideration. His studies were followed by Thurnstone. In his study, Thurstone tried to explain personality in 60 personality traits and under five general topics (Mulyanegra vd, 2009).

According to Sigmund Freud's psychoanalysis theory, personality is divided into super ego, ego and id and develops as a result of an interaction between them (İslamoğlu, 2006; http://esincolak.blogcu.com/freud-un-psikanaliz-kurami/251049, 22/03/2010). Biological drives, which carry with them sexual connotations, play a decisive role in this interaction. This approach is one of the most effective and popular personality theories of our era, even though it has experienced some changes and has been criticized because it ignored historical and sociological conditions and explained personality development only with unconscious processes (Ünlü, 2001).

Henry A. Murray, an American psychologist, enumerated approximately twenty basic needs, which each individual has, claiming that personality develops with these needs. (Onaran, 1981; http://www.botav.org/henry-alexander-murray, 22/03/2010). His list of needs established the fundamentals of the tests for evaluating personality with statistical methods. That these tests had an aim to reveal unconscious behaviors brought with them the idea that personality is a product of these unconscious processes (http://www.tegim.com/egitim/dosyalar/k-r-bolumler/psikoloji/1977-kisilik.html, 22/03/2010).

Gordon W. Allport, an American psychologist, approached personality as a whole consisted of individual and singular features. According to him, human behavior is designated by unchanging, completely subjective and singular personality features (Karakaya, 2008).

According to William McDougall's theory of personality traits, an American psychologist, personality is a whole consisted of hereditary (primary) and learned (secondary) features (Hazar, 2006). As a result of these approaches, personality traits such as sincere, assertive, emotional and conscientious were determined.

There is not a generally-accepted definition about personality and there are hundreds of scales for measuring personality traits. It is seen that most of these scales measure personality traits in different names but same dimension or vice versa. It is asserted that personality can not be measured academically unless a conceptual foundation for scales and variables about personality is created (Yelboğa, 2006).

Throughout history, psychology has tried to form a generalisable and systematic framework which can explain personality. The most comprehensive and acceptable study is five-factor model. Although there is some debate continuing, psychologists generally accept that these five-factor is enough to measure personality (Geuens et al. 2009).

Five-factor model was mentioned first in 1933 in presidential speech for American Psychological Association by L. L. Thurstone (Vikipedia, 03.02.2010). Reliability and validity of five-factor model have been verified many times in many cultures by different researchers throughout the world (Solmuş, www.xing.com, 20.03.2010). Five-factor model of personality (Big Five) took its final form with McCrea and Costa's studies which prove that the model should be accepted to measure personality (Schneider and Bodur, 2009; Mulyanegra et al, 2009).

Lewis Goldberg, Naomi Takemoto-Chock, Andrew Comrey and John M. Digman examined the personality scales and found that the personality scale Norman created in 1963 reliably measured the five general factors (Tabak et al. 2010; www.msxlabs.org, 02.03.2010). After this general acceptance of Big-five model by most researchers, The NEO Personality Inventory (NEO PI-R) was published in 1985 by Costa and McCrae. These 
five personality dimensions measured by the NEO PI-R, including facets, are as follows: (Bacanlı et al, 2009; Yürür, 2009; Larson and Sachau: 2009; Caprara et al, 2001):

$\begin{array}{ll}\text { - } & \text { Extraversion } \\ \text { - } & \text { Neuroticism } \\ \text { - } & \text { Openness to experience } \\ \text { - } & \text { Conscientiousness }\end{array}$

\section{Brand Personality and Measuring Brand Personality}

Personality which is a component of identity is of great importance for communication because if a brand has no personality, it can not introduce itself and be remembered easily. Therefore, a brand should apply a consistent image which reflects its style and to be remembered easily. Archetypes are useful tools due to being powerful personality types having deep roots in terms of mind. It is clear that brand personalities should be taken into consideration in a flexible and lively way due to the fact that they have changed for centuries (http://markakimlik.blogspot.com, 23.03.2010). The meanings a brand mentions may be in different dimensions and there may be various ways to convey those meanings (Özkan, 2005).

If the relation between consumer and brand is bigger, the rate to prefer the brand will also increase. In time, this preference can create dependence for consumer. To continue this relation, consumer must adapt the brand and bring into connection with it by personalizing. Adapting and personalizing depend on building the factors of brand personality (Yilmaz, 2007).

Studies on brand personality and personality psychology start at the same time. Brand personality is a popular metaphor which is used to reveal the role of real and ideal identities in choosing brand. Consumers are under the influence of similarities between their personalities and product they prefer among rival products (Rathnoyake, 2008). Aaker (1996) stresses that brand personality is one of fundamental dimensions of brand value. The importance of brand is mentioned more and more by specialists because brand personality increases not only consumer preference and usage, but also trust and loyalty at the same time (Aksoy and Özsomer, 2007). Practitioners and advertisers gave importance to brand personality long before academicians. Brand personality was defined as a concrete dimension among store features by Matineau (1958). Store personality or character should be used to differentiate from others (Pandey, 2009).

King (1970) and Plummer (1984) stressed on this point when studying consumer behavior. King (1970) said in his study that brand personality is useful factor in preferring one between two brands. King also stated that consumers prefer brands and friends in the same way and attribute human characteristics to their preferred brands (Cui et al, 2008; Mengxia, 2007). Plummer says that if a brand were a man, consumers ask and judge brands in their minds with questions like "How does he look like? Where does he live?, What does he do?, What kinds of magazines does he read?, What does he wear?, Who does he talk about in a party?" (Erdem, 2004).

Aaker developed a valid and reliable scale based on qualitative studies on personality and personality traits used by marketers and psychologist and formed its theoretical framework (Rojas - Mendez vd., 2004; Rojagopal, 2005).

Aaker states that two different scales can be used to measure brand personality. The first one is the scale that includes 20-300 character features. Although it seems practical and useful, some basic characters may not be noticed. Since personality traits are chosen arbitrarily, validity and reliability of the scale becomes contentious. The other brand personality scale is more theoretical and was created on human characteristics as they are. Although most of the characters match up with brands, some of them may not be adapted to brands. So Aaker tried to create a brand personality scale without those advantages (Aaker, 1997). Aaker (1997) defined brand personality as "a group of humanitarian traits that are associated to a brand". To measure brand personality, Aaker adapted five-factor theory used for personality studies in psychology to marketing (Fennis and Pruyn, 2007). Aaker reduced 114 character features to a scale consisted of 42 personality traits, 15 sub-dimensions and 5 basic dimensions (Cui et al, 2008: 532). After the study was completed, it was found out that five dimensions used to measure personality in the USA are sincereness, excitement, competency, development and robustness. With the help of those personality traits, answers (1: Can not be defined properly, 5: Defined perfectly) were obtained using 5-point grading (Aaker, 1997; Romaniuk, 2008). Validity and reliability of characters and dimensions were tested by many studies using the scale (Azoulay and Kapferer, 2003; Morschett et al. 2008).

Aaker shows in his study where theoretical framework of brand personality is defined that brand personality is 
five-dimensioned as in psychology. He asserts the dimensions are a reliable, valid, systematic and generalisable scale that can measure brand personality (Aaker, 1997; Rekom, vd., 2006).

Through sincereness dimension, Aaker points at brands used by earthly people living in a small town and are good providers. This dimension is also related to honesty, being fair, physical and mental satisfaction brand provides, as well as physical features of brand, such as color. Besides all these, by emotional aspects of brand used, helpfulness of brand like a friend is also pointed out (Mishra and Datta, 2008; Aaker, 1997). Excitement dimension is related to personality traits such as captivity, liveliness, creativity and modernity. Competency is attached to character traits such as, reliability, intelligence and success. Development dimension is a personalized dimension which is sophisticated, attractive in upper class (Rathnoyake, 2008; Mishra and Data, 2008).

Aaker defines brand personality at individual brand level and says that individual brands can be used to measure brand personality. However it is thought that five dimensions are suitable for a structure consisted of different brands and product categories. If researchers think that each individual brand have the same five-dimensioned structure or a simplified scale can be used to measure only brand, they have to be careful. In this case, Aaker's scale consisted of 42 variables and five dimensions should be revised again and adapted (Cui et al, 2008). Therefore, in this study, cell phone brands are discussed as a general category and their brand personalities are aimed to be measured.

Culture may also cause Aaker's five-dimensioned structure. When brand personalities are compared among cultures, brand perceptions are defined according to value and needs of these cultures. Differences among cultures differ when brand personalities are determined (Sung ve Tinkham, 2005).

The scale for brand personality developed by Aaker (1997) focuses on measuring brand personality according to consumer perceptions. The studies using this scale mainly measure brand personalities in western cultures. Therefore, most of the personality adjectives used in the scale is for western cultures. The personality adjectives should be adapted to the different cultures (Aksoy and Özsomer, 2007). Trade marks are identified with human characteristics. These symbolic meanings attributed to brands point out the values and beliefs of the culture (Sung and Tinkham, 2005). Thomas and Sekar (2008) used Aaker's scale consisted of 42 variables to measure brand personality of Colgate and they reached five dimensions. The studies done in Japan and Spain were carried out as five-dimensioned (Aaker et al. 2001). In the study done to measure brand personality of Ford, it was carried out as four-dimensioned (Thomas ve Sekar, 2008).

It was seen that competence and excitement dimensions were formed in every culture although adjectives vary in sub-variable forming the dimensions. It was found out that South Korea is similar to Turkey in terms of brand personality (www.ekonometrik.com.tr, 24/05/2009). It was discovered that conventional and androgenic dimensions are peculiar to Turkey. Traditionalism is often used to define Turkish culture. Androgen is used for both men and women. Androgenic dimension was seen in the studies done in South Korea (Büyükyavuz, 2008).

When Aksoy and Özsomer (2007) created the scale according to the needs and values of Turkey, they modified it to a structure that has four-dimension and 39 variables in their study which prove reliability and validity of Aaker's brand personality scale for Turkey. In our study, the scale which was ed for Turkey by Aksoy and Özsomer (table 1) is used. The study is similar to other studies carried out on the subject in terms of dimension. However the adjectives used in the study are mainly appropriate for Turkey.

\section{[INSERT TABLE 1: DIMENSIONS FORMING BRAND PERSONALITY IN TURKEY]}

\section{Methodology}

\subsection{Research Model and Hypotheses}

The aim of the study is to predict behavioral intentions of cell phone users for cell phone brands with brand personality perceptions. To reach this aim, Aaker's scale adapted by Aksoy and Özsomer (2007) was used in the study. The adjectives given at Table 1 were used to measure cell phone brand personality. The research is limited to Niğde city center. Niğde is a small city in the center of Turkey with a population of 100000 people. This is a significant limitation of the study for generalization. The aim of the research is to find out the effect of brand personality on purchase intention.

\section{[INSERT FIGURE 1: RESEARCH MODEL]}

There are many factors effecting attitude and intentions of consumer. However personality is the first one we face. Ratchford and Vaughn emphasized in their studies that situational and personality factors have determinative effect on attitudes and intentions for forming consumer behavior towards product and brand (Shavitt, 1989). In the literature, there are findings that brand personality is affected by behavioral intentions 
such as how to make consumer buy and pay more, developing his brand preference, make them tell others good things about brand (Dursun and Çerçi, 2004; Hayes, 1999). The study which studies brand personality perceptions and its effect on behavioral intentions are based on the studies in literature.

The hypostesis of the research in accordance with its model and aim is developed as follow:

H1: Consumers' perceptions of brand personality affect behavioral intentions

\subsection{Sample Selection and Sample Size}

Due to cost and time limits, judgment sampling, one of non-random samplings, was used to reach much data as quick and cost-effective as possible (Nakip, 2003). Therefore, no generalization is made using the results of the study. "To obtain normal results, each parameter in the scale should be answered by at least ten answerers when calculating sample size is large enough for the study" (Hair et al., 1998). Since there are 39 personality adjectives to measure brand personality and four variables to measure behavioral intentions, totally 43 parameters, sample size should be at least 430. The study was carried out with 490 people using judgment sampling. Thus Hair's advice for sample size was followed in the study.

\subsection{Data Gathering Method and Tool}

Data needed for analysis was gathered with questionnaire method using face-to-face interview technique. The questionnaire has three parts. In the first part, 39 personality adjectives to measure cell phone brand personality are given. In the second part, there are questions to measure their behavioral intentions (consumer's intention to buy more, his desire to pay more, developing his brand preference, telling others good things about brand). In the last part, there are questions to get to know them and information about their demographic features. Questions were formatted using 5-point Likert scale as "1: can not be defined correctly, 5: Can be defined perfectly.

\subsection{The Analysis of Data and Findings}

Exploratory Factor Analysis was used to analyze the data. Exploratory Factor Analysis aims to define the basic structure and to determine each dimension forming this structure separately. (Hair et al., 1998). Regression analysis was used in the study to predict behavioral intentions of cell phone users with brand personality. For Exploratory Factor Analysis and regression analysis, SPSS 17.0 Statistical Packet was used in the study. First of all, evaluations related to demographic questions were carried out. It was found out that $\% 62.5$ of participants are men. \% 28 of all participants are between 25 and $34 . \% 49$ are graduates of university or vocational college. \% 29 have 700-1300 \$ US monthly income. Nokia is the most owned cell phone brand with \% 37.5 .

The reliability and average of the brand personality scale used in the study are calculated as 0.949 and 3, 605, respectively. When the results of the study are compared with other studies using the same scale adapted from Aaker's by Aksoy and Özsomer, it was seen that Aksoy and Özsomer (2007), Yener (2007), Y1lmaz (2007), Büyükyavuz (2008), Çetin (2009) calculated its reliability as $0.90,0.85,0.946,0.968,0.89$, respectively. Thus, it can be said that the reliability of the study to measure brand personality is normal. The reliability and average of the scale to measure behavioral intentions were found to be 0.896 and 3.612. Cronbach's Alpha coefficient, which shows internal consistency of the variables forming the scale is used to evaluate the reliability of the study. When Cronbach's Alpha coefficient is 0.60 or less, the results related to internal consistency are not satisfactory. The value of Cronbach's Alpha should be higher than 0.70 . When it is higher, the reliability also increases due to the value of correlation coefficient between variables.

Factor analysis was used to measure the reliability of brand personality scale. 39 personality adjectives developed for Turkey by Aksoy and Özsomer (2007) were used completely and four dimensions were obtained at the end of the test. Varimax rotation was used to do the analysis. First of all, KMO and Barlett test values were examined to determine whether 39 variables could be factorized or not. KMO values were bigger than 0.50 for both scales (personality and behavioral intention). Thus 39 personality adjectives were evaluated with factor analysis. It is seen that factor loads of all dimensions are bigger than 0.50. Taking these results into consideration, it can be said that the scale measures a certain structure and the scales are valid structurally. When the variances are examined, it was seen that total variance of androgen, traditionalism, excitement, and competence whose Eigen values are bigger than 1 is 0.735 .

\section{[INSERT TABLE 2: FACTOR MATRIX]}

It is seen that cell phone brands are perceived as qualified, successful, good, original and global under competence dimension. When excitement dimension is examined, it is seen that they are perceived as tempting, cheerful and sympathetic. The underlying reason can be the effect of cell phone advertisements given lately. When traditionalism is taken into consideration, adjectives like cost-effective, classical and family-focused 
caught our attention.

This proves that Turkish consumers do not perceive cell phones as conventional. It is remarkable that femininity and ostentation come to forefront under androgenic dimension. Rotation methods were not used since the structure that measure behavioral intention (consumer's intention to buy more, his desire to pay more, developing his brand preference, telling others good things about brand) is one-dimensioned. Behavioral intention explains 0 . 85 of total variance.

Regression analysis was used to test alternative hypothesis in the study which researches the effect of consumers' perceptions of cell phone brand personality on behavioral intentions.

\section{[INSERT TABLE 3: REGRESSION MODEL]}

Table 3 gives information about the effect level. When the table is examined, correlation coefficient is 0.816 . It means that there is a strong relationship. Determination coefficient explains consumers' behavioral intentions (brand personality dimensions that are determined as competence, traditionalism, androgenic, excitement) as 0.66. The first steps of the hypothesis is proved, in other words, it can be said that brand personality has an effect on behavioral intention. To understand whether this relationship is meaningful or not, ANOVA table should be examined.

\section{[INSERT TABLE 4: ANOVA TABLE]}

Since the meaningfulness is less than 0.05 , there is a significant effect of perceived brand personality on consumers' behavioral intentions.

\section{[INSERT TABLE 5: COEFFICIENT]}

Standardized loads (B) and significance level (p) which shows the effect of competence, excitement, conventionalism, androgenic dimensions which form brand personality on behavioral intentions and relationships between them are given. In this case, the hypothesis H1 which asserts that there is a significant relationship between consumers' perception of brand personality and behavioral intentions was accepted.

One of the aims of regression analysis is to make projections about future. Thus mathematical regression model must be created. Beta coefficients in table 4 and their levels of meaningfulness give information about the usability of the model and the meaningfulness of projection that can be made for future. The mathematical model that is created is realized as follows:

$\mathrm{y}=0.032+0.758$ (competence) +0.283 (excitement) +0.061 (traditionalism) +0.102 (androgen)

It shows that when any information about created mathematical regression model and dimensions is obtained, consumers' behavioral intention can be predicted. When beta coefficients are taken into consideration, competence and excitement dimensions which are among cell phone brand personalities have more effects on consumers' behavioral intentions than any other factors. Thus, it can be said that the effect of competence and excitement dimensions on transforming. Turkish consumers' perceptions of cell phone brand personality into buying intention are higher than those of androgenic and traditionalist dimensions. That cell phones which are technological products are perceived as competent and exciting shows us that firms are also successful in positioning.

\section{Conclusion}

Conditions of competition are changing rapidly today and companies that strategize and react to these changes promptly and quickly are the most successful. Due to technological developments, physical differences of products have decreased. Differentiation should be made on the meanings products bear instead of on their physical features.

A successful brand differentiation can be possible by building personality. Thanks to brand personality, consumer sees brand as friend since it provides him with emotional benefits. A well-formed brand personality increases brand preference and usage. Also, a strong emotional tie built by brand personality ensures trust for brand.

Brand personality provides brand and firms with various benefits. The most important is that it makes brand different from others. This differentiation helps consumer for preference. In this step, brand and the meaning which brand bears and associations for consumers play important roles in consumer preference. Right brand personality formed for the needs of target market can help brand to be noticed and to be preferred. The aim of brand personality is that when consumer has difficulty in deciding, it affects his emotional decisions and makes consumer buy the brand. Brand personality gives firms a sustainable competition advantage. Original brand personality which is created against rivals can help firms have competition advantage, emphasizing on 
positioning and promotion. The preferred brands are indicators for consumers.

Brand is an important part of product policies. The possibility of brand personality measurement can contribute to product positioning and creating advertisement message and is an important element for brand extension.

Aksoy and Özsomer (2007:10) state that brand personality is defined differently in Turkey and the scales developed for other countries can not be used in Turkey. If used, it would have misleading results. Therefore, in the study, the scale adapted by Aksoy and Özsomer for Turkish culture was used to measure brand personality.

Competency and excitement dimensions are two important factors of brand personality scale in countries such as the USA, South Korea, Spain and Japan which are of different culture. In our study, it was seen that these two dimensions are also effective in Turkey.

In Turkey, a concept of being global is under competency dimension. This makes Turkish consumers perceive global brands as more competent although this does not exist in countries such as the USA, Spain. Brand personality positioning created on competency and excitement for global brands can help them enter new markets easily. Brand personality created on competency and excitement make same messages in different markets be used successfully.

In this pilot study researching the effects of consumer perception of cell phone brand personality on behavioral intentions, the effect of personality attributed to brands on behavioral intentions like preference, advice, and desire to pay more for brands was examined.

The personality adjectives adapted by Aksoy and Özsomer were used to measure the personality Turkish consumer attribute to brands because it is known that personality is affected by cultural factors. As a result of factor analysis done, it is seen that four-dimensioned brand personality was formed. The first two factors are competency and excitement. Although it is normal to perceive cell phone which is a technological product as competent, it is surprising that brands are perceived as family-focused and classical in traditionalism dimension which forms the third dimension. Additionally, it can be said that in androgenic dimension, cell phones are perceived as femininity and ostentatious. Behavioral intentions of consumers are approached as one-dimensioned. When the effect of brand personality on purchase intention for cell phone is examined, it is seen that the effect is very strong.

That the effect of competency dimension on behavioral intentions is more that those of other dimensions in terms of market share shows that global brands position themselves in the correct way in cell phone markets where global brands are in existence. It is seen that the effect of traditionalism and androgenic dimensions on behavioral intentions is smaller that others. When the brands and products are international and global, perceptions as traditional are not preferred naturally.

It is thought that personality perceptions towards cell phone brands may be effective for developing positive attitude and behavior and building brand loyalty. It is also thought that the firms who intend to enter markets should emphasize the same features so as to increase their competition chance. As a result, that knowing perceptions towards brand personality which has effects on brand preference can help firms make decisions related to brand management in a correct and effective way. Positive perceptions of brands can be used to help firms be advantageous in fierce markets. Firms should promote right brands with brand personality that can be accepted by consumers in unstable and dynamic markets. Thanks to the formed brand personality which is unique and original, the brand is differentiated from the brands which have same product features. Due to the limitations in the study, it is not possible to generalize the results. However, it is thought that the obtained findings and data in the study will be useful for similar studies in the future.

\section{References}

Aaker, J.L., V. Benet-Martinez. ve J. Garolera. (2001). Consumption Symbols as Carriers of Culture: A Study F Japanese and Spanish Brand Personality Constructs. Journal of Personality and Social Psychology, 81(3). 492-508.

Aaker Jennifer L. (1997). Dimensions of Brand Personality. Journal of Marketing Research, Vol. XXXIV, August 97.

Aksoy Lerzan ve A. Özsomer. (2007). Marka Kişiliği Tanımının Türkiye'de Geçerliliği. (Validity of Brand Personality Definition in Turkey), TÜBİTAK Proje No: 105K153, Sosyal ve Beşeri Bilimler Araştırma Grubu, Ekim 2007, İstanbul.

Aksoy Lerzan ve A. Özsomer. (2007). Türkiye'de Marka Kişiliği Oluşturan Boyutlar. (Dimensions Forming Brand Personality in Turkey), 12. Ulusal Pazarlama Kongresi Bildirisi - Sakarya Üniversitesi, 2007, 1-14. 
Azoulay, Audrey ve Jean-Noel Kapferer. (2003). Do Brand Personality Scales Really Measure Brand Personality. Brand Management, Vol. 11, No. 2, November.

Bacanli Hasan T. İlhan ve S. Aslan. (2009). Beş Faktör Kuramına Dayalı Bir Kişilik Ölçeğinin Geliştirilmesi: Sıfatlara Dayalı Kişilik Testi (SDKT). Türk Eğitim Bilimleri Dergisi, Bahar, 7(2), 261-279

Büyükyavuz Celal Özgür. (2008). Üniversite Öğrencilerinin Kullandıkları Spor Ayakkabılarına İlişkin Marka Kişiliği Algılarındaki Farklılıkların Belirlenmesine Yönelik Bir Pilot Araştırma. (A Pilot Study to Determine the Differences in Perceptions of Brand Personality Related to Trainers Worn by University Students), İstanbul Üniversitesi, Sosyal Bilimler Enstitüsü, Pazarlama Ana Bilim dalı, Yayınlanmamış Yüksek Lisans Tezi.

Caprara Gian Vittorio, C. Barbaranellı ve G. Guido. (2001). Brand Personality: How to make the metaphor fit?. Journal of Economic Psychology, 22, 377 - 395.

Chong, V.K. ve M.J. Rundus. (2004). Total Quality Management, Market Competition and Organizational Performance. The British Accounting Review, 36(2), 155-172.

CUI Annie Peng, J. Albanese Paul. Robert D. Jewell ve Michael Y. Hu. (2008). Profiling the Brand Personality of Specific Brands. Advances in Consumer Research, Volume 35, 534 - 541.

Cetin Birsen. (2009). Türkiye'de Lüks Tüketim Ürünlerinde Marka Kişiliğinin Marka Sadakatine Etkisi Ve Bir Uygulama. (Effects of Brand Personality on Brand Loyalty in Luxury Consumer Goods in Turkey), Marmara Üniversitesi, Soysal Bilimler Enstitüsü, Halkla İlişkiler Anabilim Dalı, Yayınlanmamış Yüksek Lisans Tezi.

Cetin Nesrin Gökben, E. Beceren. (2007). Lider Kişilik: Gandhi. (Leader Personality: Gandhi), Süleyman Demirel Üniversitesi Sosyal Bilimler Enstitüsü Dergisi, Y11/Volume: 3, Say1/Issue: 5, 110-132.

Çifci Sertaç, R. Cop. (2007). Marka ve Marka Yönetimi Kavramları: Üniversite Öğrencilerinin Kot Pantolon Marka Tercihlerine Yönelik Bir Araştırma. (Brand and Brand Management Concepts: A Study on Preferences of University Students for Brands of Jeans), Finans Politik \& Ekonomik Yorumlar Cilt: 44 Sayı: 512

Dursun Yunus ve M. Çerçi. (2004). Algılanan Sağlık Hizmeti Kalitesi, Algılanan Değer, Hasta Tatmini ve Davranışsal Niyet İlişkileri Üzerine Bir Araştırma. (A Study on Perceived Health Service Quality, Patient Satisfaction and Behavioral Intentions Relations), Erciyes Üniversitesi İktisadi ve İdari Bilimler Fakültesi Dergisi, Say1: 23, Temmuz-Aralık 2004, 1-16.

Dursun Tolga. (2009). Marka Kişiliği Yaratma Süreci ve Marka Kişiliği Üzerine Bir Araştırma. (Process to Create a Brand Personality and a Study on Brand Personality), Marmara İletişim Dergisi, Say1 14, Ocak 2009, İstanbul

Eisend Martin ve A. Langer. (2007). The Impact of Brand Personality Dimensions on Brand Performance. American Marketing Association, winter.

Erdem, S. (2004). Marka Değerini Oluşturan Faktörlerin Müşteri Odaklı Ölçümlenmesi ve Süt Ürünleri Sektörüne Yönelik Bir Araştırma. (Measuring the Factors Forming Brand Personality and Study on Dairy Sector), Marmara Üniversitesi Sosyal Bilimler Enstitüsü, Yayınlanmamış Doktora Tezi.

Erkal Buket. (2004). Kişilik Psikolojisi ve Kişsilik Kuramları, Davranış Bilimlerine Giriş. (Personality Psychology, Personality Theories and Introduction to Behavioral Sciences), Enver Özkalp (Editör), Anadolu Üniversitesi, AÖF Yayınları, Eskişehir.

Fennis Bob M., and H. Pruyn. (2007). You are What You Wear: Brand Personality Influences on Consumer Impression Formation. Journal of Business Research, 60 (2007) 634-639, doi:10.1016/j.jbusres.2006.06.013, http://dx.doi.org/10.1016/j.jbusres.2006.06.013

Geuens Maggie, B. Weijters ve K. De Wulf. (2009). A New Measure of Brand Personality. Intern. J. of Research in Marketing $26 \quad$ (2009) 97-107, doi:10.1016/j.ijresmar.2008.12.002, http://dx.doi.org/10.1016/j.jiresmar.2008.12.002

Hair, Joseph F. Jr. Rolph E. Andreson. Ronald L. Tahtam. William C. Black. (1998). Multivariate Data Analysis. Fifth Edition Prentice-Hall International Inc, New Jersey, USA.

Hayes James Bryan. (1999). Antecedents and Consequences of Brand Personality. Mississippi State University, Mississippi, PHD Thessis, UMI Number: 9959055.

Hazar Çetin Murat. (2006). Kişilik ve Illetişim Tipleri. (Personality and Types of Communication), Selçuk İletişim $4,2,125-140$.

Islamoğlu A. Hamdi. (2006). Pazarlama Yönetimi. (Marketing Management), Genişletilmiş Üçüncü Baskı, Beta 
Basım, İstanbul.

Jonsson P. (2000). An Empirical Taxonomy of Advanced Manufacturing Technology. International Journal of Operations \& Production Management, 20(12), 1446-1474.

Karakaya Semra. (2008). Dindarlı ve Kişilik Arasındaki Ilişski, Allport Ve Fromm'un Karşılaştırmalı Analizi. (Relationship Between Religiousness and Personality, Comperative Analysis of Allport and From) Çukurova Üniversitesi Sosyal Bilimler Enstitüsü, Yayınlanmamış Yüksek Lisans Tezi

Keller, K.L. (2003). Strategic Brand Management: Building, Measuring and Managing Brand Equity. 2nd edn, Prentice Hall, Upper Saddle River, NJ.

Kurtulus Sema Dündar. (2008). Ülkelerin Marka Kişiliği Üzerine Bir Arastırma. (A Study on Brand Personality of Countries), İktisadi ve İdari Bilimler Dergisi, Cilt: 22, Temmuz 2008, Sayı: 2, 287 - 300.

Larson Andrea J. ve A. Sachau Daniel. (2009). Effects of Incentives and the Big Five Personality Dimensions on Internet Panellists' Ratings. International Journal of Market Research, Vol. 51 Issue 5, DOI: $10.2501 / \mathrm{S} 1470785309200888$

Lee Jung Wan. (2009). Relationship between Consumer Personality and Brand Personality as Self-Concept: From the Case of Korean Automobile Brands. Academy of Marketing Studies Journal, Volume 13, Number , 25 44.

Mccrae, Robert R., and Paul T. Costa. (1987). Validation of the Five-Factor Model of Personality across Instruments and Observers. Journal of Personality and Social Psychology, 52 (January), 81-90.

Mengxia Zhang. (2007). Impact of Brand Personality on PALI: A Comparative Research between Two Different Brands. International Management Review, Vol: 3, No. 3, 36 -44.

Mishra Pallabi ve B. Datta. (2008). Consanguinity between Consumer and Brand Personality: A Review. The Icfai University Journal of Consumer Behavior, Vol. III, No. 3, 7 - 14.

Morschett Dirk, H. Klein -, F. Hälsig, ve J. Magali. (2008). The Influence of Self-Congruity, Brand Personality and Brand Performance on Store Loyalty. European Advances in Consumer Research, Volume 8, 417 - 418.

Mulyanegara Riza Casidy, Y. Tsarenko ve A. Anderson. (2009). The Big Five and Brand Personality: Investigating the Impact of Consumer Personality on Preferences towards Particular Brand Personality. Journal of Brand Management, 16, 234 - 247. published online 8 June 2007. doi:10.1057/palgrave.bm.2550093, http://dx.doi.org/10.1057/palgrave.bm.2550093

Nakip, Mahir. (2003). Pazarlama Araştırmalarii. (Marketing Researches), Ankara, Seçkin Yayıncılık.

Nart Sima. (2008). Menşe Ülke Etkisinin Tüketici Algılamaları ve Davranışlarına Yansımaları: İngiltere Pazarında Türk ve Alman Markalarının Karşılaştırılması. (The Reflection of Effects of Origin Country on Consumer Perceptions and Behaviours: Comparing Turkish and German Commodities in UK), Süleyman Demirel Üniversitesi, Ikktisadi ve İdari Bilimler Fakültesi Dergisi, C.13, S.3: 153 - 177.

Odabasi, Yavuz, G. BARIŞ. (2003). Tüketici Davranışı. (Consumer Behaviour). İstanbul: Mediacat Yayınları, 2005: 24

Onaran OĞUZ. (1981). Çalışma Yaşaminda Güdülenme Kuramları. (Motivation Theories in Business Life), Ankara Üniversitesi Siyasal Bilgiler Fakültesi Yayinları, Yayin No: 470, Sevinç Matbaası, Ankara.

Pandey, Anuja. (2009). Understanding Consumer Perception of Brand Personality, IUP Journal of Brand Management, Sep 2009, Vol. 6 Issue 3/4, p26-50,

Rathnayake C V. (2008). Brand Personality and its Impact on Brand Feelings: A Study among Young Television Viewers. South Asian Journal of Management, Apr-Jun2008, Vol. 15 Issue 2, p7-24

Ravichandran, T. ve R. Arun, (1999). Total Quality Management in Information Systems Development: Key Constructs and Relationship. Journal of Management Information Systems, 16(3), 119-156.

Rekom Johan, J. Gabriele ve P. Verlegh. (2006). Measuring and Managing The Essence of a Brand Personality. Marketing Letters, Jul 2006, Vol. 17 Issue 3, p181-192.

Rojas-Me' Ndez Jose' I., I. Podlech ve E. Olave. (2004). The Ford Brand Personality in Chile. Corporate Reputation Review, Vol. 7, No. 3, 2004, pp. 232-251.

Rojagopal. (2005). Impact of Advertising Variability on Building Customer - Based Brand Personality in a Competitive Environment: Emprical Analyis with Reference to Mexico. Latin American Business Review, Vol. 
6(3): 63 - 84. doi: 10.1300/JI40v06n03_03.

Romaniuk Jenni. (2008). Comparing Methods of Measuring Brand Personality Traits. Journal of Marketing Theory and Practice, Vol 16, 153 - 161, DOI 10.2753/MTP1069-6679160205.

Shavitt Sharon. (1989). Products, Personalities and Situations in Attitude Functions: Implications for Consumer Behavior. Advances in Consumer Research (Volume 16): 300 - 305.

Schneider Gülpınar Kelemci ve C. K. Bodur. (2009). Tüketicilerde Marka Kişiliği Algısı İle Marka Tercihine İlişkin Bir Analiz: Hijyenik Ürünler Sektöründe Bir Uygulama. (An Analysis on Brand Personality Perceptions and Brand Preferences of Consumers: An Application in Hygienic Products Sector), Dumlupinar Üniversitesi Sosyal Bilimler Enstitüsü Dergisi, Sayı 24.

Solmus Tarık, İş Yaşamında Kullanılan Kişilik Ölçüm Ararçları: Hangisi "Doğru", Hangisi "Yanlış"?. (Personality Measurement Tools in Business Life: Which is True?, Which is Wrong?), [Online] Available: www.xing.com, 03/20/2010

Soysal Abdullah. (2008). Çalışma Yaşamında Kişilik Tipleri: Bir Literatür Taraması. (Personality Types in Business Life: A Literature Review), Çimento İşveren, Ocak, 4 - 19.

Sung Yongjun ve Spencer F. Tinkham. (2005). Brand Personality Structures in the United States and Korea: Common and Culture-Specific Factors. Journal of Consumer Psychology, 15(4), 334-350.

Tabak Akif, H. N. Basım, İ. Tatar ve F. Çetin. (2010). İzlenim Yönetimi Taktiklerinde Beş Faktör Kişilik Özelliklerinin Rolü: Savunma Sanayinde Bir Araştırma. (The Role of Five-Factor Personality Traits in Impression Management Tactics), Ege Akademik Bakış, 10 (2): 539-557.

Thomas B. J. ve P. C. Sekar. (2008). Measurment and Validity of Jnenifer Aaker's Brand Personality Scale for Colgate Brand. Vikalpa, Vol 33, No. 3, Jully - September, 49 -61.

Uztug, Ferruh. (2003). Markan Kadar Konus: Marka Iletisimi Stratejileri. (Speak as much as Your Brand: Strategies for Brand Comunication), İstanbul, MediaCat Yayınları.

Unlu Sezen. (2001). PSIKOLOJİ. (Psychology), Anadolu Üniversitesi Yayın No:1288, Açıköğretim Fakültesi Yayın No:710.

Xue Ke, M. YU ve C. Liu. (2007). An Influencing Research on Brand Personality to Perceived Quality. International Journal of Business and Management, Vol.2, No. 4, 10 - 14.

Yelboga Atilla. (2006). Kişilik Özellikleri ve İş Performansı Arasındaki İlişkinin İncelenmesi. (A Study on Relationship Between Personality Traits and Work Performance), Işs, Güç Endüstri İlişkileri ve İnsan Kaynakları Dergisi Cilt:8 Say1:2, Haziran 2006, ISSN: 1303-2860.

Yener Dursun. (2007). Marka Çağrışım Unsurlarının Marka Kişiliği Üzerine Etkisi: Sütaş Markası Üzerine Bir Uygulama. (The Effects of Brand Associations Factors on Brand Personality: An Application on Sütaş Brandname), Marmara Üniversitesi, Soysal Bilimler Enstitüsü, İşletme Anabilim Dalı, Yayınlanmamış Yüksek Lisans Tezi.

Yilmaz Mesut. (2007). Marka Kişiliği Boyutları ve IKEA Uygulaması. (Brand Personality Dimensions and IKEA Application), Yıldız Teknik Üniversitesi, Sosyal Bilimler Enstitüsü, Yayınlanmamış Yüksek Lisans Tezi.

Yurur Senay. (2009). Yöneticilerin Çatışma Yönetim Tarzları ve Kişilik Özellikleri Arasındaki İlişkinin Analizine Yönelik Bir Araştırma. (A Study on Analysis of Relationship Between Personality Traits and Conflict Management Methods of Managers), C.Ü. İktisadi ve İdari Bilimler Dergisi, Cilt 10, Say1 1, 23 - 42.

http://esincolak.blogcu.com/freud-un-psikanaliz-kurami/251049, 22/03/2010

http://www.tegim.com/egitim/dosyalar/k-r-bolumler/psikoloji/1977-kisilik.html, 22/03/2010

www.ekonometrik.com.tr, 24/05/2009

www.vikipedi.com, 03/02/2010

www.donusumkonagi.net, 26/02/2010

www.msxlabs.org, 02/03/2010

http://www.bilgininadresi.net/Madde/33235, 20/03/2010

http://www.botav.org/henry-alexander-murray, 22/03/2010

http://markakimlik.blogspot.com, 23/03/2010 
http://markakimlik.blogspot.com, 23/03/2010

Table 1. Dimensions Forming Brand Personality in Turkey

\begin{tabular}{|l|l|l|l|}
\hline Competency & Excitement & Traditionalism & Androgen \\
\hline Quality & Entertaining & Economical & Masculine \\
Professional & Funny & Modest & Rebellious \\
Successful & Cheerful & Traditional & Feminine \\
Skilled & Rattling & Saving & Ostentatious \\
Trustable & Lively & Classical & \\
Prestigious & Sympathetic & Conservative & \\
Self-confident & Liberal & Family-focused & \\
Assertive & Swift & & \\
Known & Younglike & & \\
Reliable & Robust & & \\
Global & Young & & \\
Stable & Passionate & & \\
Good & Sporty & & \\
Original & Tempting & & \\
\hline
\end{tabular}

Source: Aksoy ve Özsomer, 2007: 13. 
Table 2. Factor Matrix

\begin{tabular}{|c|c|c|c|c|}
\hline & Competency & Excitement & Traditionalism & Androgenic \\
\hline Quality &, 908 & & & \\
\hline Good &, 879 & & & \\
\hline Successful &, 871 & & & \\
\hline Original &, 866 & & & \\
\hline Global &, 850 & & & \\
\hline Reliable &, 836 & & & \\
\hline Known &, 829 & & & \\
\hline Prestigious &, 828 & & & \\
\hline Trustable &, 825 & & & \\
\hline Assertive &, 821 & & & \\
\hline Stable &, 817 & & & \\
\hline Self-confident &, 810 & & & \\
\hline Skilled &, 809 & & & \\
\hline Professional &, 770 & & & \\
\hline Tempting & &, 923 & & \\
\hline Cheerful & &, 915 & & \\
\hline Sympathetic & &, 892 & & \\
\hline Robust & &, 880 & & \\
\hline Passionate & &, 876 & & \\
\hline Liberal & &, 846 & & \\
\hline Entertaining & &, 846 & & \\
\hline Funny & &, 840 & & \\
\hline Young & &, 836 & & \\
\hline Lively & &, 831 & & \\
\hline Younglike & &, 802 & & \\
\hline Sporty & &, 775 & & \\
\hline Rattling & &, 681 & & \\
\hline Swift & &, 601 & & \\
\hline Economical & & &, 859 & \\
\hline Classical & & &, 853 & \\
\hline Family-focused & & &, 803 & \\
\hline Modest & & &, 778 & \\
\hline Traditional & & &, 767 & \\
\hline Saving & & &, 736 & \\
\hline Conservative & & & ,698 & \\
\hline Faminine & & & &, 659 \\
\hline Ostentatious & & & &, 653 \\
\hline Rebellious & & & &, 560 \\
\hline Masculine & & & &, 532 \\
\hline
\end{tabular}


Table 3. Regression Model

\begin{tabular}{|c|c|c|c|c|}
\hline Model & $\mathrm{R}$ & $\begin{array}{c}\text { Determination } \\
\text { Coefficient }\end{array}$ & $\begin{array}{c}\text { Corrected } \\
\text { Determination } \\
\text { Coefficient }\end{array}$ & $\begin{array}{c}\text { Standard Error } \\
\text { of Estimate }\end{array}$ \\
\hline 1 &, $816^{\mathrm{a}}$ &, 667 &, 664 &, 58074674 \\
\hline
\end{tabular}

a. Estimators: (Invariant), Competency, Excitement, Traditionalism, Androgenic

Table 4. ANOVA Table

\begin{tabular}{|l|l|r|r|r|r|r|}
\hline \multicolumn{2}{|c|}{ Model } & Sum of Squares & $\begin{array}{c}\text { Degrees of } \\
\text { Freedom }\end{array}$ & Mean Square & F & Meaningfulness \\
\hline \multirow{3}{*}{1} & Regression & 326,967 & 4 & 81,742 & 242,365 &, $000^{\mathrm{a}}$ \\
\cline { 2 - 7 } & Remains & 163,574 & 485 &, 337 & & \\
\cline { 2 - 7 } & Total & 490,542 & 489 & & & \\
\hline
\end{tabular}

a. Estimators: (Invariant), Competency, Excitement, Traditionalism, Androgenic

b. Dependent Variable: Behavioral Intention

Table 5. Coefficient

\begin{tabular}{|c|c|c|c|c|c|}
\hline \multirow{2}{*}{ Model } & \multicolumn{2}{|c|}{ Not Standardized } & \multirow{2}{*}{$\begin{array}{c}\text { Standardized } \\
\text { Beta Coefficient }\end{array}$} & \multirow{2}{*}{$\mathrm{t}$} & \multirow{2}{*}{ Meaningfulness } \\
\hline & Coefficients & Standard Error & & & \\
\hline (Sabit) & ,032 &, 026 & & 1,215 & ,225 \\
\hline Competency &, 758 &, 026 & ,757 & 28,859 &, 000 \\
\hline Excitement & ,283 & ,026 & ,283 & 10,776 &, 000 \\
\hline Traditionalism &, 061 & ,026 &, 061 & 2,317 &, 021 \\
\hline Androgenic & , 102 & ,026 &, 102 & 3,891 &, 000 \\
\hline
\end{tabular}

a. Dependent Variable: Behavioral Intention

\section{Brand Personality}

Competency, Excitement

Traditionalism, Androgen

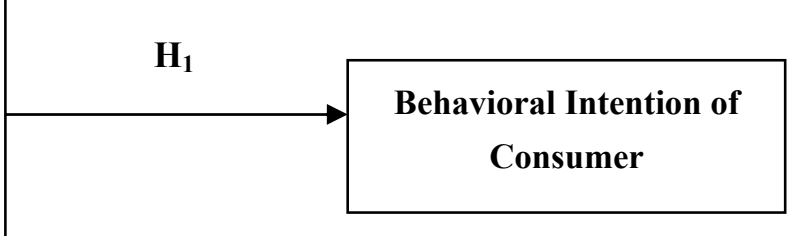

Figure 1. Research Model 